\title{
Effect of a $0.5 \%$ chlorhexidine gel on dental plaque superinfecting microorganisms in mentally handicapped patients
}

\section{Efeito do gel de clorexidina a 0,5\% em microrganismos superinfectantes da placa bacteriana de portadores de necessidades especiais}

\author{
Cláudio Mendes Pannuti* \\ Roberto Fraga Moreira Lotufo* \\ Silvana Cai** \\ Maria da Conceição Saraiva* \\ Nivea Maria de Freitas*** \\ Danilo Falsi****
}

\begin{abstract}
A randomized clinical trial was conducted to investigate the effect of a $0.5 \%$ chlorhexidine (CHX) gel on dental plaque superinfecting microorganisms in mentally handicapped patients. Thirty inmates from the institution "Casas André Luiz" were assigned to either test group (CHX gel, $\mathrm{n}=15$ ) or control group (placebo gel, $\mathrm{n}=15$ ). The gel was administered over a period of 8 weeks. Supragingival plaque samples were collected at baseline, after gel use ( 8 weeks) and 16 weeks after baseline. The presence of Gram-negative Enterobacteriaceae, Staphylococcus and yeasts was evaluated. No significant growth of any superinfecting microorganism was observed in the CHX group, when compared to the placebo group. The results indicated that the $0.5 \%$ chlorhexidine gel did not produce an undesirable shift in these bacterial populations.
\end{abstract}

DESCRIPTORS: Chlorhexidine; Cerebral palsy; Staphylococcus; Enterobacteriaceae; Yeasts.

RESUMO: Foi conduzido um ensaio clínico aleatório com objetivo de investigar o efeito do gel de clorexidina (CHX) a $0,5 \%$ sobre microorganismos superinfectantes da placa bacteriana de pacientes especiais. Trinta internos da instituição "Casas André Luiz" foram aleatoriamente divididos em grupo teste (gel de CHX, n = 15) e controle (gel placebo, $\mathrm{n}=15$ ). O gel foi utilizado por oito semanas. Amostras de placa supragengival foram coletadas no início do estudo, após o uso do gel (oito semanas) e 16 semanas após o início do estudo. Foi avaliada a presença de bacilos entéricos Gram-negativos, Staphylococcus e leveduras. Não houve diferença entre os grupos quanto à presença desses microorganismos em qualquer momento do estudo. Os resultados indicam que o gel de CHX não provocou mudanças significativas na composição desses microorganismos.

DESCRITORES: Clorexidina; Paralisia cerebral; Staphylococcus; Enterobacteriaceae; Leveduras.

\section{INTRODUCTION}

Periodontal disease is the most prevalent oral condition in institutionalized mentally handicapped patients ${ }^{4,11}$. Even though gingivitis and periodontitis can be prevented by the mechanical removal of dental plaque, efficient toothbrushing and flossing is a difficult task for mentally handicapped subjects because of their physical and mental limitations ${ }^{10}$. Consequently, the use of antimicrobial agents, such as chlorhexidine digluconate (CHX), appears to be particularly suitable for these individuals. Since mentally handicapped patients are often incapable of rinsing, CHX gel applied with trays is frequently used in institutions ${ }^{12}$.

In a previous investigation, 43 Brazilian cerebral palsied institutionalized subjects were studied. The subjects were randomly assigned to a test group (CHX gel $0.5 \%$ ) and to a control group (placebo gel). The gel was applied over a period of eight weeks. A significant decrease in interdental bleeding occurred in the test group, while the control group presented a small increase.

Chemotherapeutic products used to control dental plaque should be microbiologically asses-

*PhD in Periodontics; **PhD in Microbiology, Institute of Biomedical Sciences; *** MSc Student, Discipline of Periodontics,

School of Dentistry - University of São Paulo.

****“Casas André Luiz" - Dentistry Department. 
Pannuti CM, Lotufo RFM, Cai S, Saraiva MC, Freitas NM, Falsi D. Effect of a 0.5\% chlorhexidine gel on dental plaque superinfecting microorganisms in mentally handicapped patients. Pesqui Odontol Bras 2003;17(3):228-33.

sed in order to investigate their effect on the oral microbial flora. Microbiological sampling should demonstrate that pathogenic or opportunistic microorganisms, such as enteric rods, Staphylococcus and yeasts do not develop during the use of the agent $^{3,22}$. Staphylococcus ${ }^{13,17}$ and Enterobacteriaceae species ${ }^{15,27}$ are less susceptible to chlorhexidine than most of the other oral microorganisms. Some clinical studies have demonstrated an overgrowth of enteric rods after the use of chlorhexidine mouthrinses ${ }^{5,8}$. Other reports have demonstrated that CHX mouthrinses failed to eradicate yeasts from special patients ${ }^{29,30}$. The presence of these organisms is of clinical importance, due to their association with oral and extra-oral infections ${ }^{9,24,26}$.

We have reported a high prevalence of enteric rods, Staphylococcus and yeasts on supragingival dental plaque from institutionalized developmentally disabled subjects ${ }^{20}$. Thus, the aim of this study was to investigate the effect of a chlorhexidine gel on dental plaque enteric rods, Staphylococcus and yeasts, in institutionalized cerebral palsied patients.

\section{MATERIAL AND METHODS}

A double-blind, randomized clinical trial was conducted at the "Casas André Luiz" Hospital (Guarulhos, Brazil). Thirty cerebral palsied inmates, aged 17 to 35 years, were randomly selected from a previous study ${ }^{19}$. The institution's Ethics Committee previously approved the study.

The subjects were randomly assigned to either the test group $(n=15)$ or the control group $(n=15)$. The test group used a 0.5\% chlorhexidine gel (Fórmula \& Ação, São Paulo, Brazil), and the control group a placebo gel (quinine sulfate, Fórmula \& Ação, São Paulo, Brazil). Prior to initiating the study, the Community Periodontal Index for Treatment Needs (CPITN) was assessed to verify the presence of periodontal disease ${ }^{1}$. Subjects with advanced periodontal disease $($ CPITN $=4)$ were excluded. Two weeks before the baseline collection, all subjects in both groups received thorough dental scaling and prophylaxis, and were instructed on how to brush their teeth. Oral hygiene instructions were also given to the caregivers. One day before the beginning of the application of gel, data was collected for the Plaque Control Record ${ }^{18}$.

All participants received the gel for an 8-week period. Dental hygienists applied the gel to the upper and lower dental arches by means of flexible disposable trays (Oral-B, São Paulo, Brazil), twice daily. A volume of $12 \mathrm{ml}$ of the gel was dispensed onto the tray with syringes. During the 1-minute application, saliva and excess gel were removed with a saliva ejector.

Supragingival dental plaque samples were collected at baseline, after gel use (8 weeks) and 16 weeks after baseline. A sterile curette of standard volume $(0.1 \mathrm{ml})$ was used for collecting plaque from two first molars, previously isolated and dried. The plaque was pooled into a vial containing $2.0 \mathrm{ml}$ of VMGA III transport medium with glass beads ${ }^{16}$. The vials were maintained at room temperature, transferred to the laboratory and processed within $18 \mathrm{~h}$ after collection. At the laboratory, the vials were placed in an incubator for $30 \mathrm{~min}$ at $37^{\circ} \mathrm{C}$. Dental plaque was then dispersed with a vortex mixer at its maximal setting for $60 \mathrm{~s}$. Serial 10-fold dilutions were prepared in peptone water.

$100 \mu 1$ aliquots from the VMGA III vial (no dilution) and $100 \mu 1$ aliquots from each dilution were plated on Staphylococcus Medium 110 (Difco Laboratories, Detroit, USA) for the detection of Staphylococcus; MacConkey Agar (Probac do Brasil, São Paulo, Brazil) for the detection of Enterobacteriaceae; Sabouraud Dextrose Agar with 0.1\% chloramphenicol (Difco Laboratories, Detroit, USA) for the detection of yeasts; and Brucella Agar (Difco Laboratories, Detroit, USA) containing 5\% defibrinated sheep blood, hemin $(10 \mu \mathrm{g} / \mathrm{ml})$ and menadione $(1 \mu \mathrm{g} / \mathrm{ml})$, for determining total microbial counts. The MacConkey and Staphylococcus 110 plates were incubated aerobically at $37^{\circ} \mathrm{C}$ for $24 \mathrm{~h}$. Sabouraud agar plates were maintained at room temperature for 4 days, and Brucella plates were incubated anaerobically $\left(95 \% \mathrm{~N}_{2}\right.$ and $\left.5 \% \mathrm{CO}_{2}\right)$ at $37^{\circ} \mathrm{C}$ for $5-7$ days.

The total number of microorganisms on dental plaque was determined by counting the number of colony forming units (CFUs) on the Brucella agar. Yeasts isolates on the Sabouraud agar were characterized by means of direct examination, with lactophenol aniline cotton blue stain. MacConkey isolates were characterized according to colonial and cellular morphology and Gram-staining. Enterobacteriaceae were identified using oxidase and glucose fermentation tests, and speciated using the Enterokit B (Probac do Brasil, São Paulo, Brazil), according to the recommendations of the manufacturer. Staphylococcus 110 isolates were identified based on colonial morphology, Gram 
Pannuti CM, Lotufo RFM, Cai S, Saraiva MC, Freitas NM, Falsi D. Effect of a $0.5 \%$ chlorhexidine gel on dental plaque superinfecting microorganisms in mentally handicapped patients. Pesqui Odontol Bras 2003;17(3):228-33.

staining, oxidation-fermentation $(\mathrm{OF})$ test and a positive catalase reaction. Staphylococcus aureus was identified based on a positive tube coagulase test and a positive DNase test.

The $\chi^{2}$ (chi-square) test was used to verify if there was association between experimental groups and qualitative variables, and to assess differences between groups regarding the presence of enteric rods, Staphylococcus and yeasts. Fisher's exact test was used when the expected frequency of any cell in the table was less than five. A two-way analysis of variance for repeated measures (ANOVA) was used to verify the differences between groups (independent variable) and time (repeated measure), in relation to the total number of microorganisms (dependent variable). The Tukey's HSD test was used for multiple comparisons. For all tests, a level of significance of $\alpha<0.05$ was employed.

\section{RESULTS}

The effect of the gel on plaque and gingivitis is reported in another publication ${ }^{19}$. The patient's characteristics are presented in Table 1 . Most of the inmates had a CPITN code 3 ( 4 or $5 \mathrm{~mm}$ pocket depth) as the most severe periodontal condition, but most of the sites were code $1(42.1 \%)$ or 2 (37.9\%). There was no significant association between group and CPITN code $(\mathrm{p}=0.910)$. Forty-one percent of the subjects presented severe mental deficiency, $37 \%$ moderate, $18 \%$ mild and $2 \%$ profound. At baseline, the mean Plaque Control Record was $69.2 \%$ in the test group, and $72.7 \%$ in the control group. There was no significant difference between groups in relation to Plaque Control Record $(\mathrm{p}=0.500)$.

There was no difference between groups in relation to the mean total number of microorganisms at baseline and after the use of gel (8 weeks); however, there was a significant difference $(\mathrm{p}=0.03) 16$ weeks after baseline collection (Table 2).

Table 3 shows that there was no difference between groups in relation to the presence of enteric rods at any time during the investigation. Throughout the period of study, the most frequently isolated enteric species were Serratia marcescens (13 isolates), Citrobacter freundii (7 isolates) and Klebsiella pneumoniae (6 isolates). In 13 inmates, enteric rods comprised over $1.0 \%$ of the total cultivable flora; and in five of these 13 subjects, more than $40 \%$ of the total cultivable flora was made up of enteric rods.

Throughout the investigation there was no difference between groups in relation to the presence of Staphylococcus (Table 3). All isolates were coagulase-positive, and Staphylococcus never comprised more than $0.5 \%$ of the total number of microorganisms.

The presence of yeasts was similar in the two groups at the baseline $(p=0.42)$ and after 16 weeks $(p=0.65)$ (Table 3). However, after the use of gel ( 8 weeks), yeasts were recovered in 7 subjects of the control group and only in one patient in the test group. The difference was significant $(\mathrm{p}=0.02)$.

TABLE 1 - Background and periodontal characteristics of patients.

\begin{tabular}{|c|c|c|c|c|c|c|}
\hline & & \multicolumn{2}{|c|}{ Test } & \multicolumn{2}{|c|}{ Control } & \multirow{2}{*}{ p-value* } \\
\hline & & $\mathrm{n}(\%)$ & Mean (SD) & $\mathrm{n}(\%)$ & Mean (SD) & \\
\hline \multicolumn{2}{|c|}{ Age (years) } & $15(100.0)$ & $25.7(4.6)$ & $15(100.0)$ & $24.0(3.6)$ & 0.260 \\
\hline \multicolumn{2}{|c|}{ Time in institution (years) } & $15(100.0)$ & $20.3(6.0)$ & $15(100.0)$ & $18.5(5.7)$ & 0.410 \\
\hline \multirow{2}{*}{ Sex } & Male & $\begin{array}{ll}9 & (60.0)\end{array}$ & & $9 \quad(60.0)$ & & 0.709 \\
\hline & Female & $6 \quad(40.0)$ & & $6 \quad(40.0)$ & & \\
\hline \multirow{3}{*}{ Ethnicity } & African & $4 \quad(26.7)$ & & $3 \quad(20.0)$ & & 0.440 \\
\hline & Mulatto & $3 \quad(20.0)$ & & $(6.7)$ & & \\
\hline & Caucasian & $8 \quad(53.3)$ & & 11 (73.3) & & \\
\hline \multirow{2}{*}{ CPITN code } & 2 & $5 \quad(33.3)$ & & $7 \quad(46.7)$ & & 0.700 \\
\hline & 3 & $10 \quad(66.7)$ & & $8 \quad(53.3)$ & & \\
\hline
\end{tabular}

*p-value from $t$-test for continuous variable, and from chi-square or Fisher's test for categorical variables.

SD - standard deviation; CPITN - Community Periodontal Index for Treatment Needs. 
Pannuti CM, Lotufo RFM, Cai S, Saraiva MC, Freitas NM, Falsi D. Effect of a 0.5\% chlorhexidine gel on dental plaque superinfecting microorganisms in mentally handicapped patients. Pesqui Odontol Bras 2003;17(3):228-33.

TABLE 2 - Change in the total number ${ }^{\dagger}$ of microorganisms in the test group $(\mathrm{n}=15)$ and in the control group $(\mathrm{n}=15)$ during the trial.

\begin{tabular}{l|l|r|c|c|c}
\hline \hline \multicolumn{2}{c|}{ Trial phases } & Mean & $\begin{array}{c}\text { Standard } \\
\text { deviation }\end{array}$ & Range & p-value* \\
\hline \multirow{2}{*}{ Baseline } & Test & 7.2 & 5.0 & $0.5-16$ & 0.99 \\
\cline { 2 - 6 } & Control & 6.5 & 6.5 & $0.4-23$ & \\
\hline \multirow{2}{*}{8 weeks } & Test & 21.2 & 22.6 & $1.0-70$ & 0.99 \\
\cline { 2 - 6 } & Control & 19.1 & 29.0 & $0.2-110$ & \\
\hline \multirow{2}{*}{16 weeks } & Test & 6.3 & 11.7 & $0.16-36$ & 0.033 \\
\cline { 2 - 7 } & Control & 142 & 290 & $0.26-960$ & \\
\hline \hline
\end{tabular}

†Total number expressed in $10^{11}$.

*p-value for Tukey's test.

\section{DISCUSSION}

In this trial, we investigated the effect of a chlorhexidine gel on dental plaque superinfecting microorganisms, in cerebral palsied patients. Throughout the study there was no statistical difference in relation to the presence of enteric rods and Staphylococcus between the two groups. Nonetheless, after the gel use, the occurrence of yeasts was statistically higher in the control group than in the test group. The interpretation of this statistical difference, however, needs to be carefully done, especially because of the small sample size. The statistical difference arose because of a decrease in yeast occurrence in the test group, and an increase in the control group. Therefore, the difference can be either explained by chance or by a possible inhibitory effect of CHX. This inhibitory effect was reported by in vitro studies ${ }^{6,7}$.

The proportion of Staphylococcus and yeasts in relation to the total cultivable flora was low during the experimental period. In 13 inmates $(43.33 \%)$, Enterobacteriaceae comprised more than 1\% of the cultivable flora. One patient presented high levels of enteric rods at baseline $(70 \%)$, after 8 weeks $(74 \%)$ and after 16 weeks $(76 \%)$. According to Loes$\mathrm{che}^{14}$, if a microorganism is found to comprise at least $1.0 \%$ of the plaque at a given site, it has entered into a stable relationship with the host due to its numerical dominance. A microorganism found at low levels most likely indicates transient presence. The high levels of enteric rods reported in our investigation are not frequent in healthy subjects, but similar results had already been reported in institutionalized elders ${ }^{23}$, and intensive care medical patients ${ }^{24}$.
TABLE 3 - Infection with enteric rods, Staphylococcus and yeast in the test group $(\mathrm{n}=15)$ and in the control group $(\mathrm{n}=15)$.

\begin{tabular}{c|l|c|c|c}
\hline \hline \multicolumn{2}{c|}{} & $\begin{array}{c}\text { Baseline } \\
\mathrm{n}(\%)\end{array}$ & $\begin{array}{c}8 \text { weeks } \\
\mathrm{n}(\%)\end{array}$ & $\begin{array}{c}16 \text { weeks } \\
\mathrm{n}(\%)\end{array}$ \\
\hline \multirow{4}{*}{ Enteric rods } & Test & $7(46.6)$ & $7(46.6)$ & $5(33.3)$ \\
\cline { 2 - 5 } & Control & $3(20.0)$ & $7(46.6)$ & $7(46.6)$ \\
\cline { 2 - 5 } & p-value* & 0.12 & 1.00 & 0.44 \\
\hline \multirow{4}{*}{ Staphylococcus } & Test & $1(6.6)$ & $2(13.3)$ & $7(46.6)$ \\
\cline { 2 - 5 } & Control & $3(20.0)$ & $2(13.3)$ & $5(33.3)$ \\
\cline { 2 - 5 } & p-value* & 0.30 & 1.00 & 0.44 \\
\hline \multirow{5}{*}{ Yeast } & Test & $3(20.0)$ & $1(6.6)$ & $3(20.0)$ \\
\cline { 2 - 5 } & Control $^{2}$ & $5(33.3)$ & $7(46.6)$ & $4(26.6)$ \\
\cline { 2 - 5 } & p-value* & 0.42 & 0.02 & 0.65 \\
\hline \hline
\end{tabular}

*p-value from Fisher's test.

There are several factors that may account for the high proportions of enteric rods. Some of the inmates had recently taken antibiotics, which can lead to an overgrowth of these organisms ${ }^{21}$. Also, inadequate sanitary conditions may be a source for oral colonization with Enterobacteriaceae spe$\operatorname{cies}^{2,28}$. In spite of adequate sanitary conditions at the institution, it is known that mentally handicapped subjects may have inadequate habits such as drinking inappropriate water, and even taking fecal material to their mouths. Another possibility is that a prolonged transportation time of samples in VMGA III medium may have allowed multiplication of enteric species ${ }^{2}$. We have tried to minimize this problem, processing the samples within 18 hours after collection.

The high prevalence of superinfecting organisms found in our study can represent a risk for oral and extra-oral infections. It has been reported that Enterobacteriaceae, Staphylococcus and yeasts are associated with refractory periodontal disease $^{25}$. These organisms may also disseminate into the bloodstream and colonize remote sites, leading to systemic infections ${ }^{9}$. Recent investigations have demonstrated that dental plaque can be a potential reservoir for Enterobacteriaceae and Staphylococcus - which are considered respiratory pathogens. Aspiration of salivary and dental plaque respiratory pathogens could be a risk factor for pneumonia ${ }^{23,24}$ in these patients.

Based on the findings of these investigations and the Pannuti et al. ${ }^{19}$ study, we concluded that the $0.5 \%$ chlorhexidine gel was efficient and safe. The product was capable of reducing interdental bleeding, and it did not promote any undesirable 
Pannuti CM, Lotufo RFM, Cai S, Saraiva MC, Freitas NM, Falsi D. Effect of a $0.5 \%$ chlorhexidine gel on dental plaque superinfecting microorganisms in mentally handicapped patients. Pesqui Odontol Bras 2003;17(3):228-33.

shift in the colonization patterns of enteric rods, Staphylococcus and yeasts, when compared to the placebo. Based on our results it can be suggested that the application of CHX gel can be safely indicated as an adjunct to mechanical plaque removal for cerebral palsied subjects. However, we stress that it cannot completely replace toothbrushing and interdental cleaning; efforts should thus be made to ensure the instruction and motivation of patients and caretakers in relation to the mechanical removal of plaque.

\section{REFERENCES}

1. Ainamo J, Barmes DE, Beagrie G, Cutress T, Martins J. Development of the World Health Organization (WHO) community periodontal index of treatment needs. Int $\mathrm{J}$ Dent Res 1982;32:281-91.

2. Ali RW, Velcescu C, Jivanescu MC, Lofthus B, Skaug N. Prevalence of 6 putative periodontal pathogens in subgingival plaque samples from Romanian adult periodontitis patients. J Clin Periodontol 1996;23:133-9.

3. American Dental Association. Guidelines for acceptance of chemotherapeutic products for the control of supragingival dental plaque and gingivitis. J Am Dent Assoc 1986; 112:529-32.

4. Brown JP. The efficacy and economy of comprehensive dental care for handicapped children. Int Dent J 1980; 30:14-27.

5. Brown AT, Sims RE, Raybould TP, Lillich TT, Henslee TJ, Ferretti GA. Oral Gram-negative bacilli in bone marrow transplant patients given chlorhexidine rinses. J Dent Res 1989;68:1199-204.

6. Candido RC, Azevedo RV, Ito IY. Determinação da concentração inibitória mínima de Cepacol, Malvona e Periogard, ante a Candida albicans isoladas da cavidade bucal. Rev Odontol UNESP 1996;25:79-84.

7. Denton GW. Chlorhexidine. In: Block SS. Disinfection, sterilization and preservation. $3^{\text {rd }}$ ed. Philadelphia: Lea $\&$ Febinger; 1991. p. 438-52.

8. Ferretti GA, Raybould TP, Brown AT, MacDonald JS, Greenwood M, Maruyama Y, et al. Chlorhexidine prophylaxis for chemotherapy- and radiotherapy-induced stomatitis: a randomized, double-blind trial. Oral Surg Oral Med Oral Pathol 1990;69:331-8.

9. Fourrier F, Duvivier B, Boutigny H, Roussel-Delvallez M, Chopin C. Colonization of dental plaque: a source of nosocomial infections in intensive care unit patients. Crit Care Med 1998;26:301-8.

10. Francis JR, Hunter B, Addy M. A comparison of three delivery methods of chlorhexidine in handicapped children. J Periodontol 1987;58:451-5.

11. Francis JR, Stevenson DR, Palmer JD. Dental health and dental care requirements for young handicapped adults in Wessex. Community Dent Health 1991;8:131-7.

12. Gabre P, Gahnberg L. Dental health status of mentally retarded patients with various living arrangements. Spec Care Dent 1994;14:203-7.

\section{CONCLUSIONS}

The $0.5 \%$ chlorhexidine gel did not promote a shift in the colonization patterns of Gram-negative enteric rods, Staphylococcus and yeasts, when compared to the placebo. In $43.3 \%$ of the inmates Enterobacteriaceae comprised more than $1 \%$ of the cultivable flora. The most frequent enteric species isolated were Serratia marcescens (13 isolates), Citrobacter freundii (7 isolates) and Klebsiella pneumoniae (6 isolates).

13. Kampf G, Jarosch R, Ruden H. Limited effectiveness of chlorhexidine based hand disinfectant against methicillin-resistant Staphylococcus aureus (MRSA). J Hosp Infect 1998;38:297-303.

14. Loesche WJ. Ecology of oral flora In: Nisengard RJ, Newman MG. Oral Microbiology and Immunology. $2^{\text {nd }}$ ed. Toronto: W.B. Saunders; 1988. p. 308.

15. Mengistu Y, Erge W, Bellete B. In vitro susceptibility of Gram-negative bacterial isolates to chlorhexidine. East Afr Med J 1999;76:243-6.

16. Möller AJ. Microbiological examination of root canals and periapial tissues of human teeth. Methodological studies. Odontol Tidskr 1966;Dec 20;74:Suppl:1-380.

17. Nicoletti G, Boghossian V, Gurevitch F, Borland R, Morgenroth $P$. The antimicrobial activity in vitro of chlorhexidine, a mixture of isothiazolinones ("Kathon" CG) and cetyl trimethyl ammoniun bromide (CTAB). J Hosp Infect 1993;23:87-111.

18. O'Leary TJ, Drake RB, Naylor JE. The plaque control record. J Periodontol 1972;43:38.

19. Pannuti CM, Lotufo RFM, Saraiva MC, Cai S, Ferraro A, Falsi D. Effect of $0.5 \%$ chlorhexidine gel on special patients. J Clin Periodontol (in press).

20. Pannuti CM, Lotufo RFM, Cai S, Freitas N, Ferraro AQ. Prevalência de microrganismos superinfectantes na placa bacteriana de deficientes mentais institucionalizados. RPG Rev Pos Grad 2001;8:35-9.

21. Rams TE, Babalola OO, Slots J. Subgingival occurrence of enteric rods, yeasts and Staphylococci after systemic doxycycline therapy. Oral Microbiol Immunol 1990;5:166-8.

22. Ranney RR. Criteria for efficacy of plaque control agents for periodontal disease: microbiology. J Dent Res 1989; 68:1655-60.

23. Russel SL, Boylan RJ, Kaslick RS, Scannapieco FA, Katz $\mathrm{RV}$. Respiratory pathogen colonization of the dental plaque of institutionalized elders. Spec Care Dent 1999; 19:128-34.

24. Scannapieco FA, Stewart EM, Mylotte JM. Colonization of dental plaque by respiratory pathogens in medical intensive care patients. Crit Care Med 1992;20:740-5.

25. Slots J, Rams TE, Listgarten MA. Yeasts, enteric rods and pseudomonads in the subgingival flora of severe adult periodontitis. Oral Microbiol Immunol 1988;3:47-52. 
Pannuti CM, Lotufo RFM, Cai S, Saraiva MC, Freitas NM, Falsi D. Effect of a 0.5\% chlorhexidine gel on dental plaque superinfecting microorganisms in mentally handicapped patients. Pesqui Odontol Bras 2003;17(3):228-33.

26. Slots J, Feik D, Rams TE. In vitro antimicrobial sensitivity of enteric rods and pseudomonads from advanced adult periodontitis. Oral Microbiol Immunol 1990;5:298-301.

27. Slots J, Rams TE, Schonfeld SE. In vitro activity of chlorhexidine against enteric rods, pseudomonads and acinetobacter from human periodontitis. Oral Microbiol Immunol 1991;6:62-4.

28. Slots J, Rams TE, Feik D, Taveras HD, Gillespie GM. Subgingival microflora of advanced periodontitis in the Dominican Republic. J Periodontol 1991;62:543-7.
29. Spijkervet FKL, van Saene HKF, Panders AK, Vermey A, van Saene JJ, Mehta DM, et al. Effect of chlorhexidine rinsing on the oropharyngeal ecology in patients with head and neck cancer who have irradiation mucositis. Oral Surg Oral Med Oral Pathol 1989;67:154-61.

30. Thurmond JM, Brown AT, Sims RE, Ferreti GA, Raybould TP, Lillich TT, Henslee PJ. Oral Candida albicans in bone marrow transplant patients given chlorhexidine rinses: occurrence and susceptibilities to the agent. Oral Med 1991;72:291-5.

Recebido para publicação em 18/12/02

Enviado para reformulação em 28/05/03

Aceito para publicação em 03/06/03 